La Ley de Separación de 1905: luces y sombras en la génesis de la idea de laicidad en Francia

\title{
The French Law of Separation of 1905: perspectives on the genesis of the idea of «laïcité» in France
}

\footnotetext{
Alejandro TORRES GUTIÉRREZ

Catedrático de Universidad, Área de Derecho Constitucional

Departamento de Derecho Público, Universidad Pública de Navarra

alejandro.torres@unavarra.es
}

Resumen: Este artículo analiza críticamente la gestación de la Ley de Separación francesa de 1905, su contexto social, las líneas básicas de su contenido, especialmente el significado y alcance de las asociaciones cultuales y el fin de la financiación estatal a los cultos reconocidos napoleónicos, así como su acogida por la Iglesia, la crisis en las relaciones Iglesia-Estado, y el itinerario recorrido hasta la resolución del problema con la adopción de la fórmula de las asociaciones diocesanas. Reflexionase sobre la génesis traumática del principio de laicidad y sus consecuencias, al redefinir una nueva legislación estatal, cuyas consecuencias llegan hasta nuestros días.

Palabras clave: Laicismo, laicidad, separación, libertad religiosa, confesiones religiosas, Francia

\begin{abstract}
This paper analyzes critically how the French Law of Separation of 1905 came into being, explaining its social context, its main contents, and especially, the meaning and scope of the so-called associations of cult, and the end of public financial support for recognized religious cults established in Napoleonic times. It describes its reception by the Church, the crisis in the relations between Church and State, and the long march towards the resolution of this problem, through the adoption of the new category of diocesan associations. We reflect on the traumatic genesis of the idea of laïcité, and how this affected changes in legislation, whose consequences are still in force.
\end{abstract}

Keywords: Laicism, secularism, separation, religious freedom, religious groups, France

\section{LA GÉNESIS DE LA LEY DE SEPARACIÓN DE 9 DE DICIEMBRE DE 1905}

\section{I.1. El estado de la cuestión al comenzar la VIII legislatura}

Paradójicamente, al comenzar la VIII Legislatura en 1902, nada parecía indicar que la cuestión de la separación entre el Estado y la Iglesia se encontrase entre las prioridades a abordar durante la misma, con contadas excepciones, como la habida con motivo del primer congreso del partido radical y radical-socialista, que se celebra en 1901, donde Léon Bourgeois había abogado por una nítida fórmula separatista, 
y dirigido un llamamiento al cierre de filas, pues no debía haber divergencias el día en que el Concordato fuera hecho añicos. Pero en realidad ese no había sido el verdadero eje sobre el que habían girado los programas, en un proceso electoral en el cual de lo que realmente se había discutido no era otra cosa que la política llevada a cabo por el gabinete de Waldeck-Rousseau ${ }^{1}$. No en vano, a poco de comenzar, el 12 de junio de 1902, en contestación a una pregunta del diputado socialista Jaurès sobre este particular, Combes le responderá que el momento de la separación no habia llegado todavía. Combes pensaba que la Iglesia católica era mucho más fácilmente controlable siendo financiada por el Estado, que separada del mismo, de ahí su interés inicial por aprovechar todos los recovecos instrumentalizadores que el Concordato le ofrecía ${ }^{2}$.

\section{I.2. Las proposiciones de ley previas}

Los primeros cuatro proyectos presentados tendrán una neta inspiración jacobina o separatista. Son los de Victor-Léon Dejeante y Maurice Allard (27 de junio de 1902), Ernest Roche (20 de octubre de 1902), Francis de Pressensé (7

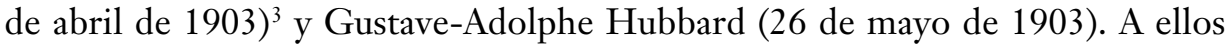
siguen otros tres proyectos más liberales, favorables a la libertad de las iglesias, el de Émile Florens (7 de junio de 1903), Eugène Réveillaud y Louis Méjan (25 de junio de 1903), y el de Georges Grosjean y Georges Berthoulat (29 de junio de 1903). Cada uno tenía detrás a su propia clientela (desde las extrema izquierda socialista a la derecha nacionalista, con la implicación de protestantes

1 Remi Fabré, L'élaboration de la loi de 1905, en Patrick WeIL, Politiques de la Laïité au XXe siècle, PUF, París, 2007, p. 49.

2 A título personal se mostraba favorable Camille Pelletan (Ministro de Marina). Brigitte BASDEVANT-GaudemeT, State and Church in France, en Gerhard RobBERS (ed.), State and Church in the European Union, Nomos Verlagsgesellschaft, Baden-Baden, 2005, p. 160. Jean FOYER, La genèse de la loi de séparation, en Archives de Philosophie du Droit, 48, 2004, pp. 75 y ss. Anatole FRANCE, L'Eglise et la Republique, Bosch, Utrecht, 1964, p. 41. Maurice LARKIN, L'Église et l'État en France. 1905: La crise de la Séparation, Privat, Toulouse, 2004, p. 112. Jean Paul SCOT, L'État chez lui, l'Église chez elle. Comprendre la loi de 1905, Le Seuil, París, 2005, pp. 154 y 175176.

3 Que a la postre será el que sirva de base principal en la redacción final de la Ley, y que además de en las ideas de católicos como el cardenal Manning (el cual veía en una sana separación, una posible vía de revitalización de la Iglesia católica), está muy especialmente inspirado, en las doctrinas republicanas de la soberanía y de la laicidad, así como en el separatismo protestante. Remi FABRÉ, L'élaboration de la loi de 1905, en Patrick WEIL, Politiques de la Laïcité au XXe siècle, PUF, París, 2007, p. 50. 
y católicos), y no todos reunían la misma calidad técnica. El 18 de junio de 1903, la Cámara de Diputados designa finalmente una comisión compuesta por 33 diputados, de los cuales 17 eran a priori partidarios de la separación, pues procedían del Bloque de Izquierdas), mientras que 16 eran contrarios a ella. Como ponente provisional es designado el socialista Aristide Briand, abogado y periodista, bohemio, colaborador habitual en el periódico La Lanterne, de marcada orientación anticlerical, y fundador con Jean Jaurès del diario L'Humanité, calificado satíricamente por Clemenceau como Sarto-Briand (en alusión al apellido de Pío X), o un socialista papista ${ }^{4}$ (por su tendencia a desmarcarse de postulados anticlericales extremistas, habiendo incluso dejado hacer a su hija la primera comunión), al tratar de buscar una fórmula final que no fuera demasiado inasumible por parte de la Iglesia 5 .

\section{I.3. El anteproyecto de Briand}

\section{I.3.1. Contexto}

La Comisión encargada de preparar la Ley, decide en su primera sesión por 17 votos frente a 15, que ha lugar para separar las Iglesias y el Estado y comenzar el examen de los sistemas diversos propuestos para reemplazar el régimen del Concordato ${ }^{6}$, así como no adoptar como propio ninguno de los siete proyectos presentados

4 Socialiste papalin, sic.

5 Dos eran las principales perspectivas sobre cómo regular la cuestión religiosa, la primera de ellas, sostenida por Aristides Briand, buscaba una ley honesta que no fuese una pistola apuntando a la Iglesia, la segunda, defendida por Clemenceau, reivindicando la Revolución que debe tomarse entera como un bloque, que es la que finalmente se impone, produciéndose un radical régimen de separación, que se iniciara con la Revolución. Una visión global y muy didáctica del problema puede verse en Patrick CABANEL, 1905, la séparation des Églises et de l'État en 30 questions, Geste, La Crèche, 2005. Asimismo son de interés: Jean BAUBÉROT y Micheline MiLOT, Laïcités sans frontières, Seuil, París, 2011, p. 261. Jean Michel DucOMTE, La Loi de 1905. Quand l'État se séparait des Églises, Milan, Toulouse, 2005, pp. 26 y 27. Miguel Ángel JuSDADO RUIZ-CAPILLAS, Laicismo en Francia: Precedentes de la Ley de separación de 1905. (En el Centenario de la Ley), en Anuario de Derecho Eclesiástico del Estado, 22 (2006), p. 349. Jacqueline LALOUETTE, La séparation des églises et de l'État, Éditions du Seuil, París, 2005, p. 410. Maurice LARKIN, L'Église et l'État en France. 1905: La crise de la Séparation, Privat, Toulouse, 2004, pp. 123 y ss. Jean Paul SCOT, L'État chez lui, l'Église chez elle. Comprendre la loi de 1905, Le Seuil, París, 2005, pp. 133 y 135. Samuel TOMÉI, Ferdinand Buisson, séparatiste radical, en Jean-Marc SCHIAPPA (coord.), 1905! La loi de séparation des Églises et de l'État, Syllepse, París, 2005, pp. 123 a 134.

6 Véase la intervención de Eugène Réveillaud en la sesión de la Cámara de Diputados de 4 de abril de 1905, con ocasión de los debates de la Ley de separación. Anales de la Cámara de Diputados de 4 de abril de 1905, p. 1506. 
hasta ese momento, y encargar a Briand la elaboración de un nuevo texto, que deberá de redactar durante el verano de 1903, a modo de tarea para las vacaciones. $S u$ primer anteproyecto, deudor del trabajo de Pressensé, es entregado a sus colegas de la comisión, el 8 de octubre de $1903^{7}$.

A principios de 1904, comenzaba a cristalizar como hipótesis con visos de realidad el que la separación pudiera ser algún día una hecho consumado, aunque más dudas cabían sobre el cuándo iba a llegar esa fecha ${ }^{8}$. Los acontecimientos políticos mientras tanto se precipitan. La controversia a raíz del viaje de Loubet a Roma en el mes de abril de ese año, va a tener como colofón unas consecuencias imprevistas, y las dificultades en la designación de las sedes episcopales vacantes se enquistan. La ruptura de relaciones diplomáticas con la Santa Sede está cerca. En este contexto políticamente caldeado, un hecho que resulta particularmente sorprendente es que a pesar del clima pasional que rodeaba la materia que debía regularse, el millar y medio de folios que recogen las actas de los trabajos de la comisión, plasman una atmósfera de trabajo serena. Es de este modo como se llega al anteproyecto de la comisión, también conocido como anteproyecto Briand, que será finalmente adoptado por unanimidad, el 6 de julio de $1904^{9}$.

\section{I.3.2. Contenido}

El artículo 1 del anteproyecto comienza afirmando que La República garantiza la libertad de conciencia así como la libre expresión de opiniones religiosas, y el artículo 2 en el que se establece que La República no protege, ni retribuye, ni subvenciona, bajo cualquier forma y por cualquier razón que sea, ningún culto.

El finiquito del presupuesto de culto y clero venía contemplado en el artículo 5 del anteproyecto, que preveía la supresión del mismo a partir del 1 de enero

7 Nótese por el lector el irónico empleo de la cursiva a la hora de atribuir la paternidad del texto a Briand, porque en realidad las pruebas de filiación sobre el mismo habrían puesto de relieve que tenía un segundo progenitor, el también diputado socialista Pressensé, que no formó parte de la comisión, pero cuyo proyecto había servido de cañamazo básico sobre el cual Briand había trabajado. Pressensé guardará un discreto (y generoso), silencio sobre este particular, para conseguir que la Ley saliera finalmente adelante.

8 Louis CAPÉRAN, L'invasion lä̈que. De l'avènement de Combes au vote de la séparation, Desclée de Brouver \& Cie, París, 1935, p. 341.

9 Jean Michel Ducomte, La Loi de 1905. Quand l'État se séparait des Églises, Milan, Toulouse, 2005, pp. 24 y 25. Jean Paul SCOT, L'État chez lui, l'Église chez elle. Comprendre la loi de 1905, Le Seuil, París, 2005, p. 189. 
del año siguiente a la entrada en vigor de la Ley. Un tema sobre el que se suscitó un amplio debate en la comisión, pues no faltaron los partidarios de adoptar el modelo separatista belga, en virtud del cual el Estado mantenía el presupuesto de cultos. La réplica de un modelo más laico consistirá en alegar que el sistema belga no era un verdadero sistema de separación ${ }^{10}$.

Otra cuestión controvertida va a ser el debate sobre la propiedad de los edificios de culto, una vieja reivindicación de la Iglesia, y de los diputados católicos, a lo largo de todo el siglo XIX, que piden la restitución de los bienes confiscados durante la Revolución. La comisión decide distinguir entre aquellos edificios anteriores al Concordato de 1801 (unas 34.000 iglesias municipales y otras 879 iglesias y 85 catedrales estatales, y 5.500 edificios anexos), que eran y deberían permanecer como propiedad del Estado o de las corporaciones locales, y aquellos adquiridos o construidos con posterioridad al mismo por los establecimientos públicos de culto (apenas 1.700 iglesias y unos 1.400 edificios anexos), y que permanecerían como propiedad de los mismos, salvo en el caso de haber sido construidos con dinero público, una fórmula que será rechazada por los socialistas Allard, Dejeante y Vaillant, que pedían simple y llanamente el retorno a manos públicas de todos los bienes eclesiásticos. La fórmula propuesta por la comisión será que los edificios públicos anteriores al Concordato que estuvieran afectos a los cultos y a sus ministros, estuvieran sujetos a un arrendamiento a título oneroso por un período de 10 años, no pudiendo superar el precio del alquiler el 10\% de los ingresos anuales medios de la circunscripción religiosa afectada calculada sobre la media de los habidos en los últimos 5 años. Los inquilinos deberían correr asimismo con los gastos de mantenimiento y conservación de tales edificios ${ }^{11}$.

$\mathrm{Y}$ es aquí cuando se nos presenta el que probablemente fuera el verdadero meollo de la Ley, dilucidar a qué tipo de asociaciones se iba a devolver los medios materiales necesarios para la práctica de culto, algo a lo que se dedicará el Título IV del anteproyecto. La cuestión clave era definir el nuevo estatuto jurídico de lo que van a ser las asociaciones cultuales, a las que se va a atribuir en el artículo 19 del anteproyecto, el derecho de constituir uniones con administración o dirección central en conformidad con el decreto de 16 de agosto de 1901, que desarrollaba la Ley de asociaciones de 1 de julio de $1901^{12}$.

\footnotetext{
10 Jean Paul SCOT, op. cit., pp. 133 y 135.

11 Ibid., p. 195.

12 Ibid., pp. 196 y 197.
} 


\section{I.3.3. La acogida del anteproyecto Briand y el desarrollo de los acontecimientos políticos y sociales}

El texto del Anteproyecto Briand es adoptado por la comisión el 6 de julio de 1904, ese día es precisamente el de la víspera de la prohibición del ejercicio de la enseñanza a las congregaciones religiosas, faltando poco tiempo para la ruptura de relaciones diplomáticas con la Santa Sede. Cabe reconocer que la conclusión de los trabajos no podía haber sido más oportuna, porque en caso de saltar por los aires el Concordato, la República podía contar con materiales de trabajo con los que comenzar a definir el nuevo marco legislativo.

Es un momento de ebullición ideológica, y política también. El 28 de octubre de 1904 estalla el asunto de las fichas ${ }^{13}$, al descubrirse que oficiales de ideología monárquica o credo católico, al ser considerados como personas peligrosas para la República (o al menos de dudosa lealtad hacia ella), estaban siendo fichados con ayuda de la masonería del Grand Orient ${ }^{14}$, por el Ministro de la Guerra, general André, el cual se apresura a negar que estuviera al corriente de los hechos ${ }^{15}$. El general, abrumado por lo que la prensa está revelando, termina presentando su dimisión. Combes, balbuceando, pone en duda la autenticidad de los documentos que están saliendo a la luz pública, y hace creer que él no sabe nada. Todo ello acontece unido a una serie de interpelaciones parlamentarias a medida que se van desvelando por los periódicos los detalles del escándalo, lo que convierte a los últimos meses del Gabinete de Combes en un verdadero calvario, el cual finalmente deberá presentar su dimisión el 18 de enero de $1905^{16}$.

\section{I.4. El proyecto de Combes}

Entre tanto, el 29 de octubre de 1904 se hace público un nuevo proyecto de Ley de separación, especialmente demandado desde la extrema izquierda de la

13 Affaire des fiches, sic.

14 Estando especialmente implicado en ello su secretario general, Vadécard.

15 La muerte en extrañas circunstancias de Gabriel Sybeton, el 8 de diciembre de 1904, diputado por París, líder de la derecha nacionalista francesa que se había enfrentado el 4 de noviembre al general André a raíz del escándalo de las fichas, no hace sino añadir más tensión al conflicto. Aparentemente había tenido lugar por asfixia a consecuencia del gas proveniente de su chimenea, y la policía concluye que puede tratarse de un suicidio, pero pronto surgen las acusaciones de que se trata de un crimen detrás del cual tal vez estuviera la francmasonería o la policía secreta.

16 Daniel Amson, La Querelle religieuse, Odile Jakob, París, 2004, pp. 281 y 282. Jean CARPENTIER y François LEbrun, Histoire de France, Ed. du Seuil, París, 2000, p. 298. Maurice LaRKIN, L'Église et l'État en France. 1905: La crise de la Séparation, Privat, Toulouse, 2004, p. 151. 
Cámara, que se deposita el 10 de noviembre, respaldado por el propio Combes, que es considerado como una nueva Constitución Civil del Clero ${ }^{17}$.

Mantiene formalmente la Dirección de Cultos y guarda silencio sobre la embajada ante el Vaticano. Los lugares de culto quedarán en manos de las confesiones religiosas de manera gratuita por un período de 2 años, pero transcurrido el mismo, su disfrute se hará a título de arrendamiento por períodos renovables de 10 años. Los fondos de reserva de las asociaciones cultuales no podrán superar $1 / 3$ de sus ingresos anuales, un nivel ridículamente bajo, que les impediría contar con un solvente margen de maniobra de cara a acometer proyectos económicos en el futuro, que supusieran importantes desembolsos. Los extranjeros no podrán desempeñar el puesto de ministros de culto, quedando en todo caso sometidos a la obligación de residir en el departamento en cuestión ${ }^{18}$. La afectación de bienes al culto quedará subordinada a la previa emisión de un decreto del Consejo de Estado, o a una resolución del prefecto. Se limitan las manifestaciones públicas de culto, y más concretamente las procesiones religiosas, salvo las relacionadas con ceremonias funerarias ${ }^{19}$. Por todo ello estamos ante un texto fuertemente restrictivo, se trata más bien de una Iglesia encadenada al Estado, que separada de él ${ }^{20}$.

\section{I.5. Caída de Combes y elaboración del proyecto de ley definitivo}

La debilidad en la que Combes se encontraba era manifiesta, a pesar de haber presidido uno de los más longevos gabinetes de la III República (aparte del de Waldeck-Rousseau), pues el escándalo de las fichas le ha dejado verdaderamente tocado políticamente, contribuyendo a la caída de su Gabinete, el 18 de enero de 1905 , no sin antes cerrar esa misma mañana 466 establecimientos de las congregaciones religiosas, siendo sustituido en la Presidencia del Gobierno por Maurice Rouvier, que hasta entonces había ocupado con Combes la cartera de Hacienda, el cual toma posesión el 24 de enero de $1905^{21}$.

Caído Combes, el nuevo Presidente Maurice Rouvier, acostumbrado a flotar en medio de las tempestades, constituye un gabinete a su imagen y semejanza,

17 Le règne concordataire sans le Concordat, sic.

18 Artículo 6 del proyecto.

19 Artículo 11 del proyecto.

20 Louis CAPÉRAn, L'invasion lä̈que. De l'avènement de Combes au vote de la séparation, Desclée de Brouver \& Cie, París, 1935, pp. 355 y 356. Jean Michel DucOMTE, La Loi de 1905. Quand l'État se séparait des Églises, Milan, Toulouse, 2005, p. 25. Jean Paul SCOT, L'État chez lui, l'Église chez elle. Comprendre la loi de 1905, Le Seuil, París, 2005, p. 210.

21 Permanecerá en el cargo hasta su dimisión el 7 de marzo de 1906, y será durante su mandato cuando la Ley de separación vea la luz verde en el Parlamento. 
compuesto por radicales y moderados, entre los cuales había muchos hombres de finanzas, algo que mueve a Clemenceau a afirmar que no es un Consejo de ministros, es un Consejo de administración. Es la presión separatista lo que le lleva a tener que poner al frente de la cartera de Instrucción Pública y de Cultos a Bienvenu-Martin, en lugar de al, tal vez, más conciliador Briand. El nuevo Ministro de Instrucción Pública, Bellas Artes y Cultos, Bienvenu-Martin, desea colaborar con la comisión y hace redactar un nuevo proyecto de Ley próximo al primer texto de la comisión, que queda depositado en la Cámara de Diputados el 9 de febrero de $1905^{22}$.

Briand procura buscar una solución que pudiera ser aceptada por los católicos, o al menos por el sector más liberal de los mismos, intensificando sus contactos directos con personalidades de dicho ámbito ideológico como monseñores Fuzet (arzobispo de Rouen), y Lacroix (obispo de Tarentaise). El 4 de marzo de 1905, Briand presenta su Informe, asumiendo el compromiso de desmantelar la obra legislativa de Napoleón en materia de relaciones entre el Estado y las confesiones religiosas, y el 21 de marzo comienza el debate en la Cámara. Las discusiones parlamentarias pronto trascienden de las cuatro paredes del Palais Bourbon, para encender una controversia nacional.

\section{LOS DEBATES PARLAMENTARIOS DE LA LEY DE SEPARACIÓN}

\section{II.1. La discusión sobre el artículo 4: la espinosa cuestión de las asociaciones cultuales}

Una de las cuestiones claves a dilucidar era qué entidad iba a ser la sucesora en la titularidad de los bienes y derechos de los establecimientos públicos de culto. A estos efectos, el artículo 4 del proyecto elaborado por la comisión hacía una parca referencia a que la misma fuera hecha a las asociaciones que serán legalmente formadas para el ejercicio del culto en las antiguas circunscripciones de los citados establecimientos ${ }^{23}$.

En la sesión parlamentaria del 20 de abril de 1905, Briand propondrá dar una nueva redacción a dicho artículo 4, precisando que la atribución se realizaría a las asociaciones que ajustándose a las reglas de organización general del culto, cuyo ejercicio se propongan asegurar, sean legalmente formadas, siguiendo las prescripciones del

22 Emmanuel BARBIER, Histoire du catholicisme liberal et du catholicisme social en France, Du Concile Vatican à l'avènement de S.S. Benoît XV (1870-1914), T. IV, Imp. Cadoret, Burdeos, 1923-1924, p. 27.

23 Patrick CABANEL, Entre religions et laïcité. La voie française: XIXe-XXIe siècles, Privat, París, 2007, p. 79 y 80. Jacqueline LaloueTte, La séparation des églises et de l'État, Éditions du Seuil, París, 2005, p. 408. 
articulo $17^{24}$, para el ejercicio de este culto en las antiguas circunscripciones de los citados establecimientos ${ }^{25}$.

En la votación sobre la redacción del artículo 4, que tiene lugar el 22 de abril de 1905, 482 diputados lo hacen a favor (contando los sectores laicos convencidos, con el apoyo de la mayor parte de los católicos, pues salvo 9 diputados irreducibles, el resto han escuchado a Albert de Mun, que desaconseja tensar en exceso las cosas), por tan sólo 52 en contra, correspondientes a los sectores laicistas más radicales, que son los grandes derrotados. Con clarividencia, Jaurés exclama, La séparation c'est faite. ${ }^{26}$.

\section{II.2. Aprobación de la ley en la Cámara de Diputados y ulterior debate $y$ aprobación en el Senado}

La Ley de separación será aprobada en la Cámara de Diputados, el 3 de julio de 1905, por 341 votos a favor y 233 en contra (el 59\% de los votos emitidos), contando con el apoyo de los diputados del Bloque de Izquierdas ${ }^{27}$, y tres diputados de centro derecha, Stanislas de Castellane (Cantal), Edmond Bartissol (Pirineos-Orientales) y Henri Tournade (Sena). El gran triunfador había sido Aristide Briand. El católico Albert de Mun invitaba a los lectores de la Croix, a marcar dicha fecha como un día de luto ${ }^{28}$.

Al día siguiente de haber sido votado el proyecto en la Cámara de Diputados, el Ministro de Cultos Bienvenu-Martin lo deposita en el Senado, en donde es elegida una comisión mayoritariamente favorable a la separación. Su presidente será Vallé, un hombre próximo a Combes, y el ponente, Maxime Lecomte, un anticlerical convencido. El 13 de julio la comisión se reúne, y a propuesta de Bienvenu-Martin, se acuerda su tramitación por el procedimiento de urgencia. En cinco sesiones culmina la discusión, y a resultas de la misma es adoptado el texto, sin modificación alguna. A lo largo del verano de 1905 se suceden las declaraciones de políticos de izquierda dando por hecha la separación, y que sería una realidad antes de fin de año. El 30 de octubre, Maxime Lecomte deposita su

\footnotetext{
24 El artículo 19, del texto definitivo de la Ley.

25 Anales de la Cámara de Diputados de 20 de abril de 1905, p. 2007.

26 ¡La separación está becha!

27 Antes del escrutinio, Combés había manifestado su voto favorable a la Ley, sin renunciar a modificar los defectos que creía que la aquejaban, unas declaraciones que no podían despertar las inquietudes de los católicos, confirmando la opinión de aquéllos que creían que las concesiones de Briand tenían un carácter precario.

28 four de deuil, sic.
} 
Dictamen. El 9 de noviembre comienza el debate en el Senado. La tramitación de urgencia es aprobada por 171 votos contra 107. Es rechazado el centenar largo de enmiendas presentadas. Clemenceau lanzará una ácida crítica al artículo 4, por reconocer a los católicos el derecho a organizar sus asociaciones cultuales conforme a las normas del Derecho Canónico ${ }^{29}$.

La Ley será votada en el Senado el 6 de diciembre de 1905, por 181 votos a favor y 102 en contra (el 64\% de los votos emitidos). Dos días después, el periódico La Croix publicaba un artículo de Albert de Mun que llevaba como significativo título el de Consummatum est, en que se decía que la sentencia puesta por el Sanedrín masónico ba sido ejecutada. Cristo ba dejado de ser en Francia oficialmente reconocido. Es promulgada el día 9 de diciembre, y publicada en el fournal Officiel el 11 del mismo mes ${ }^{30}$.

\section{LA CLAVE DE BÓVEDA DE LA LEY DE SEPARACIÓN: LAS ASOCIACIONES CULTUALES}

El nuevo esquema legal diseñado por la Ley de separación girará sobre las denominadas asociaciones cultuales, previstas en su artículo 4, cuyo fin sería proveer al mantenimiento de los gastos de culto ${ }^{31}$ y a las cuales serían transferidos los bienes muebles e inmuebles de las rentas eclesiásticas, fábricas, consejos presbiterales, consistorios y otros establecimientos públicos, con todas las cargas y obligaciones que les graven, y con su afectación especial al culto, previéndose un plazo máximo de 1 año para la constitución de las mismas ${ }^{32}$.

Las asociaciones cultuales recogidas en el artículo 4 de la Ley de separación, son vistas como una provocación por amplios sectores de la Iglesia católica, pues escapan de la autoridad de los obispos, y eran un atentado a la constitución jerárquica de la Iglesia. Para tratar de eludir un eventual rechazo de la jerarquía católica, se añadirá la fórmula según la cual, su constitución se haría de conformidad a las reglas de organización general del culto, cuyo ejercicio pretendieran asegurar ${ }^{33}$, de modo

29 Louis CAPÉRAn, L'invasion läque. De l'avènement de Combes au vote de la séparation, Desclée de Brouver \& Cie, Paris, 1935, pp. 425 a 442, Jacqueline LALOUETTE, La séparation des églises et de l'État, Éditions du Seuil, París, 2005, p. 414.

30 Jacqueline Lalouette, La séparation des églises et de l'État, Éditions du Seuil. París. 2005, p. 416. Jean-Marie MaYEur, La separation de l'Eglise et de l'État. (1905), Firmin-Didot, París, 1966, pp. 92 y 93 .

31 Artículo 18 de la Ley de separación.

32 Artículo 4 de la Ley de separación.

33 Aux règles d'organisation générale du culte dont elles se proposen d'assurer l'exercice. 
que la jerarquía católica pudiera augurar un cierta expectativa de mantenimiento de su autoridad sobre las mismas, así, los fieles deberían de estar en comunión con sus curas, éstos con sus respectivos obispos, los cuales lo estarían a su vez con el soberano pontífice ${ }^{34}$. Una fórmula de compromiso añadida por Briand ${ }^{35}$.

La jerarquía católica temía la aparición de una serie de asociaciones, que reivindicasen ser parte de la Iglesia católica, pero que escapasen de su control, y en que la toma de decisiones estuviera exclusivamente en manos de laicos ${ }^{36}$.

$\mathrm{Al}$ tener que estar organizadas en el marco de los respectivos municipios, y no tomar en cuenta las particularidades de cada confesión religiosa, este sistema era particularmente inadecuado para el caso de la Iglesia católica, que se organizaba en diócesis y parroquias, pudiendo corresponder a cada municipio más de una parroquia. Además este sistema podía dar lugar a divisiones que pudieran atentar a la unidad de la Iglesia católica y a su estructura jerárquica, siendo este el principal escollo que suscita el rechazo de Pío X, a pesar del parecer de la mayor parte de los obispos franceses, que pudieran haber llegado a aceptarlas, si Roma lo hubiera hecho ${ }^{37}$.

Como hemos visto, el artículo 4 de la Ley de separación de 1905 contemplaba la creación de las denominadas asociaciones cultuales ${ }^{38}$, a las que en el plazo máximo de un año a partir de la promulgación de la Ley, serían transferidos los bienes muebles e inmuebles eclesiásticos, con todas sus cargas y obligaciones, manteniendo su afectación especial. Para poder proceder a ello, el artículo 3 de la Ley de separación encomendaba a los agentes de la administración pública a proceder al inventario:

1) De los bienes mobiliarios e inmobiliarios de los establecimientos de culto.

2) De los bienes del Estado, de los departamentos y de los ayuntamientos que los citados establecimientos tuvieren en usufructo.

En caso que los establecimientos eclesiásticos a extinguir, no hubieran procedido a la atribución de sus bienes, en el plazo de un año, sería provisto por de-

34 Jean-Louis DE LANESSAN, L'État et les églises en France depuis les origines jusqu'à la séparation. Félix Alcan Editeur, París, 1906, p. 273.

35 Louis CAPÉRAn, L'invasion lä̈que. De l'avènement de Combes au vote de la séparation, Desclée de Brouver \& Cie, París, 1935, p. 402.

36 Brigitte BaSdevant-Gaudemet, State and Church in France, en Gerhard RobBers (ed.), State and Church in the European Union, Nomos Verlagsgesellschaft, Baden-Baden, 2005, pp. 163-164.

37 Maurice BARBIER, La Laïcité, L'Harmattan, París, 1995, p. 49.

38 Hasta que no estuvieran constituidas las asociaciones cultuales, continuarían provisionalmente funcionando los establecimientos de culto cuya supresión era ordenada por el artículo 2 de la Ley de separación, conforme a lo dispuesto en el artículo 3 de la propia Ley. 
creto, mientras tanto, y hasta que no se procediera a dicha atribución, tales bienes serían colocados bajo secuestro ${ }^{39}$. Era una forma de incentivar la constitución de las asociaciones cultuales. A falta de una asociación apta para recibir los bienes de un establecimiento público de culto, los mismos serían atribuidos por decreto a los establecimientos municipales de asistencia o de beneficencia situados en los límites territoriales de la circunscripción eclesiástica afectada ${ }^{40}$.

Larkin no duda en calificar a la encíclica Gravissimo Officii, que condena la constitución de dichas asociaciones cultuales, como funesta, pues la considera como un verdadero suicidio legal al obligar a sacrificar un enorme patrimonio, privando a la Iglesia de los medios para reconstituir nuevas fuentes materiales sobre una base jurídica sólida. Poulat estima en la elevada cifra de 400 millones de francos de la época, el valor de los bienes de los establecimientos de culto suprimidos, que fueron atribuidos a los establecimientos municipales ${ }^{41}$.

Un grave problema se planteaba de este modo en el caso de la Iglesia católica, a raíz del frontal rechazo a las asociaciones cultuales, por parte de la jerarquía eclesiástica, por ello, a instancias de Aristide Briand, el Parlamento aprueba la Ley de 2 de enero de 1907, en virtud de la cual, a falta de constitución de una asociación cultual, los edificios afectos al ejercicio público del culto continuarán siendo dejados a disposición de los fieles y de los ministros de culto para la práctica de su religión. Y una Ley de 13 de abril de 1908, con el fin de resolver problemas, atribuirá a las corporaciones municipales, la propiedad de las iglesias proveniente de los antiguos establecimientos de culto, quedando las entidades municipales encargados de su mantenimiento, y la Iglesia como usufructuaria de dichos bienes destinados al culto católico ${ }^{42}$.

Apenas dos centenares se habían constituido al votarse la petite loi de 2 de enero de 1907. Con ello queda suprimida la necesidad de constituir asociaciones cultuales. La mayoría de las creadas con anterioridad dejan de operar a partir de ese momento, y apenas una quincena son declaradas hasta noviembre de $1908^{43}$.

39 Artículo 8 de la Ley de separación de 1905.

40 Artículo 9.1 de la Ley de separación de 1905.

41 Maurice LARKIN, L'Église et l'État en France. 1905: La crise de la Séparation, Privat, Toulouse, 2004, p. 185 y 189. Émile POULAT, Aux carrefours stratégiques de l'Église de France. XXe siècle, Berg International, París, 2009, p. 53.

42 Jean Michel Ducomte, La Loi de 1905. Quand l'État se séparait des Églises, Milan, Toulouse, 2005, p. 32.

43 Jean-Pierre Chantin, Les cultuelles: des catholiques contre Rome?, en Jean-Pierre CHANTIN y Daniel Moulinet (dir.), La Séparation de 1905. Les hommes et les lieux, Les editions de l'atelier, París, 2005 , pp. 111 y 112. 
El artículo 2 de la Ley de separación consagraba que la República no reconoce, ni paga, ni subvenciona ningún culto. Ello tenía como consecuencia inmediata que a partir del 1 de enero siguiente a su promulgación, serían suprimidos de los presupuestos del Estado, de los departamentos y de los ayuntamientos, todas las partidas de gastos relativas al ejercicio de los cultos. Solamente se contemplaba en la Ley una excepción que hacía referencia al mantenimiento de las dotaciones públicas para los servicios de las capellanías y destinadas a asegurar el libre ejercicio de los cultos en los establecimientos públicos, tales como los liceos, colegios, escuelas, hospicios, asilos y prisiones.

\section{LA RESPUESTA DE LA IGLESIA CATÓLICA ANTE LA LEY}

\section{IV.1. La Iglesia francesa ante la encrucijada de aceptar o rechazar la Ley}

Llama la atención el significativo mutismo inicial que guarda la Santa Sede, y ello pese a que desde allí no se es para nada ajeno a los acontecimientos que se están sucediendo en Francia. Pío X se muestra prudente, y prefiere callar hasta que el reglamento administrativo de desarrollo de la Ley no fuera publicado, la experiencia relativamente reciente hacía temer por una indeseada versión de unos eventuales e inesperados nuevos artículos orgánicos, como ocurriera un siglo antes con el Concordato napoleónico. Pocos días más tarde, el 5 de enero de 1906, llega al Vaticano el padre Le Doré, anotando Pío X tras esta visita, que la impresión del clérigo francés era que la Ley de separación era incluso peor que la Constitución Civil del Clero, que los artículos orgánicos y que las leyes de mayo ${ }^{44}$ de tiempos de la Kulturkampf destinadas a poner a raya a los católicos en la Alemania de Bismarck, y que la legislación secularizadora de la escuela francesa. A su regreso a Francia, el religioso se va de la lengua en una entrevista a La Libre

44 La denominación de leyes de mayo toma su nombre del mes en que se aprobaron. En mayo de 1873 el Estado impone la formación de los teólogos en las Universidades, así como los exámenes de Estado para el clero, el juicio del clero por tribunales especiales y el reemplazamiento de los vicarios capitulares por funcionarios. En mayo de 1874 se decreta que el clero que se hubiera resistido a las leyes de mayo de 1873 sea sometido a una serie de sanciones, entre las cuales estaría la privación de la nacionalidad alemana. Las leyes de mayo de 1875 expulsan a las congregaciones religiosas, salvo aquéllas que se dedican a asistencia a los enfermos, atribuyendo la gestión de los bienes de la Iglesia a los laicos. Además el clero es obligado a prestar un juramento semejante al de los funcionarios. Jeannine SIAT, Le Kulturkampf: crise politique, crise religieuse? en Brigitte CARRIER-REYAUD (dir.), Histoire de la religion et de la culture en Europe de 1800 à 1914, Ellipses, París, 2001, p. 75. 
parole, publicada el 28 de enero, erigiéndose en portavoz de las intenciones de la Santa Sede, sin que nadie se lo hubiera pedido, manifestando que el Papa se inclinaba por la resistencia a la Ley, siendo desmentido por L'Osservatore Romano, el 5 de febrero de 1906, en una nota que le desautorizaba como portavoz oficioso del pensamiento del Pontífice ${ }^{45}$.

\section{IV.2. La crisis de los inventarios y la encíclica Vehementer nos,} de 11 de febrero de 1906

Briand había aventurado que la reforma así hecha (será) de una aplicación fácil. Los hechos pronto desmentirán su optimista pronóstico ${ }^{46}$. El artículo 3 de la Ley de separación de 1905 preveía que una vez promulgada la misma, se procedería por parte de los agentes de la administración de bienes a la realización de un inventario de los muebles e inmuebles de los establecimientos públicos de culto, así como de los bienes del Estado, los departamentos y los municipios, cuyo uso y disfrute estaba en manos de dichos establecimientos. Las cláusulas contenidas en el artículo 3 de la Ley de separación habían pasado sorprendentemente desapercibidas durante los debates parlamentarios habidos con ocasión de la misma. En teoría, las fábricas parroquiales tenían obligación de llevar un inventario de sus bienes, a partir de una Ley que databa de 1809 , pero en la práctica esta obligación no se había observado. La necesidad de realizar tales inventarios, introducida a raíz de una enmienda de Alexandre Ribot, en el fondo había sido considerada como una mera formalidad administrativa, con el fin de proceder a la transferencia de los bienes de las fábricas concordatarias a las nuevas asociaciones cultuales, creadas por el artículo 4 de la Ley, y había obtenido un amplio respaldo parlamentario, que sobrepasaba la mayoría del Bloque de Izquierdas $^{47}$.

El Decreto regulador de la realización de los inventarios había aparecido el 29 de diciembre de 1905, pero la crisis se desencadena a raíz de una Instrucción de la Dirección General del Tesoro, de 2 de enero de 1906, en que se desliza una frase que hace estallar el polvorín social, al permitir a los agentes

\footnotetext{
45 Jean Marie MaYeur, La separation de l'Eglise et de l'État (1905), Firmin-Didot, París, 1966, pp. 109 y 110.

46 Jean BAUBÉROT, Histoire de la laïité en France, Presses Universitaires de France, París, 2000, p. 79.

47 Jean SÉvillia, Quand les catholiques étaient hors la loi, Perrin, París, 2006, p. 196. Guillaume Tronchet, Le cabinet Rouvier et l'administration préfectorale dans la crise des Inventaires (janvier-mars 1906), en Patrick WEIL, Politiques de la Laïcité au XXe siècle, PUF, París, 2007, p. 79.
} 
encargados de realizar el registro de bienes, poder pedir a los sacerdotes presentes en la operación, que les fueran abiertos los sagrarios donde se guardaba el Santísimo Sacramento, algo que hería profundamente los sentimientos de los católicos, al tocar el corazón de las creencias de la fe católica, la presencia real de Jesucristo en la hostia. La apertura de los sagrarios es vista como un sacrilegio, y el inventario como un preludio del espolio, un primer paso para el embargo de los bienes de la Iglesia.

Los primeros disturbios empiezan el 1 de febrero, con el inventario de bienes en la Iglesia de Santa Clotilde, en el $7^{\circ}$ distrito de París, en que se levantan barricadas callejeras, y en el interior es apilado un montón de sillas, detrás de las puertas de la entrada principal, para dificultar el acceso de la fuerza pública, que tras una verdadera batalla campal, consigue entrar en el templo; al día siguiente los incidentes se repiten en la iglesia de Saint Pierre-du-Gros-Caillou, en el mismo distrito parisino, entrando la policía por la fuerza, tras romper una puerta a hachazos, terminando los incidentes tras la batalla campal desatada en el interior del templo, con más de medio centenar de detenidos, y un elevado número de heridos ${ }^{48}$.

La Santa Sede, que ha guardado una exquisita prudencia ante el preocupante desarrollo de los acontecimientos, se decide finalmente a pronunciarse, a raíz de la crisis de los inventarios de los bienes del clero, viene con retraso, pero la respuesta es clara y decidida, saliendo a la luz la encíclica Vehementer Nos, con fecha de 11 de febrero de 1906, aunque probablemente llevaba ya un cierto tiempo gestándose, de modo que son los dramáticos sucesos a raíz de la elaboración de

48 Daniel Amson, La Querelle religieuse, Odile Jakob, París, 2004, p. 288. Patrick CABANEL, Entre religions et laïcité. La voie française: XIXe-XXIe siècles, Privat, París, 2007, pp. 87 y 88. Francis DÉMIER, La France du XIXe siècle. 1814-1914, Éditions du Seuil, París, 2007, p. 397. Yves-Marie HILAIRE, Vers de nouveaux rapports entre les Eglises et l'Etat, en Gérard CHOLVY y Patrick CABANEL, La révolte des Inventaires, en Jean-Pierre CHANTIN y Daniel Moulinet (dir.), La Séparation de 1905. Les hommes et les lieux, Les editions de l'atelier, París, 2005, p. 93. Yves-Marie HILAIRE, Histoire religieuse de la France Contemporaine. 1880/1930, Privat, Toulouse, 1986, pp. 111 y ss. Laurent JOLY, Les nationalistes et la loi de Séparation (1905-1906) en Patrick WeIL, Politiques de la Laïité au XXe siècle, PUF, París, 2007, p. 99. Maurice LARKIN, L'Église et l'État en France. 1905: La crise de la Séparation, Privat, Toulouse, 2004, pp. 210 y ss. Anne-Marie MAUDIT y Jean MAUDIT, La France contre la France. La séparation de l'Église et de l'État. 1900-1906, Plon, París, 1984, pp. 297 y ss. Jean-Marie MAYEUR, La separation de l'Eglise et de l'État (1905), Firmin-Didot, París, 1966, pp. 111 a 113. Pierre PIERRARD, Un siècle de l'Église de France. 1900/2000, Desclée de Brouwer, París, 2000, p. 45. Jean Paul SCOT, L'État chez lui, l'Église chez elle. Comprendre la loi de 1905, Le Seuil, París, 2005, p. 272. Jean Paul SCOT, Gènese de la loi de 1905, en Charles Yves ZARKA, Faut-il reviser la Loi de 1905? Presses Universitaires de France, París, 2005, pp. 46 y 47. Jean SÉVILLIA, Quand les catholiques étaient hors la loi, Perrin, París, 2006, pp. 196 y ss. 
los inventarios, lo que precipita la respuesta de Pío X, deseoso de dar una señal clara a los católicos franceses, al condenar el régimen de separación, e instar al episcopado francés a oponerse a la aplicación de la Ley, renunciando a una eventual tentación acomodaticia al nuevo texto ${ }^{49}$.

El 25 de febrero, 14 obispos son designados unilateralmente por la Santa Sede, por primera vez en muchos siglos, a fin de cuentas era un efecto colateral de la crisis de relaciones Iglesia-Estado, que reforzaba notablemente a la primera. Pío $\mathrm{X}$ deja entrever a los nuevos obispos que su posición se declina por el rechazo a las asociaciones cultuales previstas por la Ley de separación, invitándoles a huir de toda tentación de contemporización con el Estado ${ }^{50}$.

\section{IV.3. La búsqueda de soluciones acomodaticias: la convocatoria de la asamblea plenaria del episcopado y las tesis de los cardenales verdes}

Monseñor Lecot, arzobispo de Burdeos, prepara un modelo de estatutos de la asociación diocesana de la Gironde, que será declarada el 17 de febrero de 1906, ${ }^{51}$ que serán modificados el 16 de marzo de ese mismo año ${ }^{52}$, no sobreviviendo a la muerte de su fundador, el 19 de diciembre de 1908, siendo clausurada el 15 de febrero de 1909, a instancia de su sucesor, monseñor Andrieu. En opinión de Poulat, sus estatutos no presentaban incompatibilidad alguna con la Ley de asociaciones de 1 de julio de 1901, y los correlativos derechos de la jerarquía eclesiástica (como pronto le sería objetado). Al frente de la misma se erigía un consejo central presidido por el arzobispo, y un comité de dirección, con carácter delegado del anterior y funciones ejecutivas. A ello se unía la previsión de la existencia de una asamblea general y una serie de secciones parroquiales ${ }^{53}$. De

49 Patrick Cabanel, 1905, la séparation des Églises et de l'État en 30 questions, Geste, La Crèche, 2005, p. 12. Patrick CABANEL, La révolte des Inventaire, en Jean-Pierre CHANTin y Daniel Moulinet (dir.), La Séparation de 1905. Les hommes et les lieux. Les editions de l'atelier, París, 2005, p. 93. Philippe PORTIER, L'épiscopat français et la loi de Séparation. Retour sur un processus de reconnaissance, en Patrick WeIL, Politiques de la Laïcité au XXe siècle, PUF, París, 2007, p. 210. Émile POULAT, Les Diocesáines, La documentation Française, París, 2007, pp. 44 y ss.

50 Sobre Portugal véase el excelente estudio: João María Félix DA COSTA SEABRA, O Estado e a Igreja em Portugal no início do Século XX. A Lei da Separação de 1911, Principia, Cascais, 2009.

51 Y sus estatutos publicados en el fournal Officiel el 27 de febrero.

52 Los estatutos será publicados en el Bulletin religieux de l'archidiacre de Bourdeaux, correspondientes a los días 13 y 20 de abril de 1906, pp. 214 a 219 y 227 a 239, respectivamente.

53 Émile Poulat, Les Diocesáines, La documentation Française, París, 2007, pp. 58 y ss. 
haberse generalizado esta fórmula, pudiera haber anticipado la resolución del conflicto en dos décadas.

La comisión preparatoria de la Asamblea Plenaria del episcopado francés adopta el anteproyecto de estatutos de las asociaciones cultuales canónicas, preparado en abril de 1906 por monseñor Fulbert Petit, arzobispo de Besançon y monseñor Catteau, obispo de Luçon. Dichas asociaciones cultuales canónicas, no podrían ser formadas sin el acuerdo del obispo respectivo, su fundador debería ser un sacerdote que contara con la aprobación del obispo de la diócesis ${ }^{54}$, cada asociación debería estar vinculada a la unión diocesana que cada obispo constituiría ${ }^{55}$.

El 26 de marzo de 1906, el periódico Le Figaro, publicaba una carta suscrita por una serie de notables católicos franceses, muchos de ellos miembros de la Academia Francesa o del Instituto de Francia, entre los que se encuentran figuras como Ferdinand Brunetière (escritor y crítico literario), Denis Cochin (escritor y diputado conservador), Georges Goyau y Paul Thureau-Dangin (historiadores), o políticos como Castelnau, vinculado al partido Action Libérale, por la que hacían un llamamiento a los obispos a aceptar la Ley. La presencia de varios académicos entre los firmantes, provoca que se les ponga el apodo de cardenales verdes,${ }^{56}$ en referencia al color de las vestimentas académicas. Proponían de este modo entrar en el juego de las asociaciones cultuales, contempladas en la Ley de separación, cuyos miembros estarían en comunión con su cura párroco, éste con su obispo, y este último con el Pontífice. Los firmantes de la carta se mostraban escépticos sobre una eventual solución diferente a la legalmente contemplada, pues la búsqueda de una fórmula de persona jurídica alternativa a las asociaciones cultuales devendría ilegal, y serían disueltas por el Estado, corriéndose el riesgo de convertir el catolicismo en una religión privada. Además advertían que con la Ley en la mano, en caso de no proceder a la realización de los inventarios y constituir las oportunas asociaciones cultuales, se corría el riesgo que el Estado procediese simple y llanamente a la confiscación de los bienes de la Iglesia, algo a lo que estaría perfectamente legitimado por el propio tenor de la Ley, y convertirlos en graneros de beno o salas de danz $a^{57}$. La carta de los cardenales verdes

\footnotetext{
54 Artículo 1 del Proyecto de estatutos orgánicos para las asociaciones cultuales católicas.

55 Artículo 3 del Proyecto de estatutos orgánicos para las asociaciones cultuales católicas.

56 Es decir, cardinaux verts, sic.

57 Jean-Louis DE LANESSAN, L'État et les églises en France depuis les origines jusqu'à la séparation, Félix Alcan Editeur, París, 1906, p. 273. Jean-Marie MAYEUR, La separation de l'Eglise et de l'État (1905), Firmin-Didot, París, 1966, pp. 149 a 154. Pierre PIERRARD, Un siècle de l'Eglise de France. 1900/2000, Desclée de Brouwer, París, 2000, p. 47.
} 
disgusta a Roma, y el diario La Croix, de 24 de marzo, se hace eco de la necesidad de resistir a la $\mathrm{Ley}^{58}$.

Las elecciones legislativas celebradas a dos vueltas el 6 y el 20 de mayo de 1906, dan como resultado un avance del Bloque de Izquierdas, que gana unos 60 diputados más, formándose una mayoría suficiente con la unión de radical socialistas, radicales independientes y republicanos independientes, que no van a tener necesidad de contar con los socialistas para formar Gobierno. El resultado de las elecciones excluía la posibilidad de modificación de la Ley de separación, con independencia que fuera sensatamente aconsejable proceder con moderación a la hora de la aplicación de la misma.

Los obispos se adhieren a los postulados de la Vebementer nos, en materia de asociaciones cultuales, por 72 votos a favor y tan sólo 2 en contra, pero se aprecia un sentir muy mayoritario de intentar buscar un modus vivendi, consistente en crear asociaciones que sin violar la Ley de separación, mantuvieran a salvo los derechos de la Iglesia, lo cual obtiene el respaldo de 48 votos frente a 26. En una tercera votación, por 56 votos contra 18, se aprueba el proyecto de asociaciones canónicas legales, abanderado por monseñor Fulbert Petit, arzobispo de Besançon ${ }^{59}$, pero de cuya legalidad dudaban algunos políticos como Jacques Piou y juristas como Émile Chénon ${ }^{60}$.

Estas fórmulas acomodaticias serán objeto de un meridiano rechazo por parte de la Congregación de asuntos eclesiásticos extraordinarios, que comienza a examinar la documentación remitida desde Francia el 9 de junio de 1906. La respuesta oficial de la Santa Sede no se produce de inmediato, sino que se demorará por espacio de prácticamente un mes, quizás porque se esté a la expectativa de una eventual propuesta de negociación proveniente del Gobierno francés, que

58 Emmanuel BARBIER, Histoire du catholicisme liberal et du catholicisme social en France. Du Concile Vatican à l'avènement de S.S. Benoît XV (1870-1914), t. 4, Imp. Cadoret, Burdeos, 1923-1924, p. 153. Jean-Marie MAYEUR, La separation de l'Eglise et de l'État. (1905), Firmin-Didot, París, 1966, pp. 155 a 159.

59 Patrick Cabanel, 1905, la séparation des Églises et de l'État en 30 questions, Geste, La Crèche, 2005, p. 13. Jean-Marie MAYEUR, La separation de l'Eglise et de l'État. (1905), Firmin-Didot, París, 1966, pp. 125 y 160 a 163. Christian SORREL, Les évéques à l'heure de la Séparation, en Jean-Pierre Chantin y Daniel Moulinet (dir.), La Séparation de 1905. Les hommes et les lieux, Les editions de l'atelier, París, 2005, p. 59.

60 Bruno Dumons y Daniel Moulinet, Les laïss catholiques face à la Séparation, en Jeasn-Pierre Chantin y Daniel Moulinet (dir.), La Séparation de 1905. Les hommes et les lieux, Les editions de l'atelier, París, 2005, pp. 75 y 77, Jean Paul SCOT, L'État chez lui, l'Église chez elle. Comprendre la loi de 1905, Le Seuil, París, 2005, p. 278. 
con el paso de los días demuestra no ser otra cosa que un vano espejismo. La encíclica Gravissimo Officii despejara eventuales dudas ${ }^{61}$.

\section{IV.4. El rechazo vaticano a las asociaciones cultuales: la encíclica Gravissimo Officii de 10-14 de agosto de 1906}

La toma de posición oficial vaticana, finalmente se produce por medio de una nueva encíclica, la Gravissimo Officii, que pese a llevar fecha de 10 de agosto, ve la luz el día 14 en L'Osservatore Romano, en la que se rechaza cualquier experimento o ensayo de asociación cultual, por entender que es una fórmula contraria a la estructura jerárquica de la Iglesia católica. A los ojos de Pío X, no se trata de una Ley de separación, sino de opresión de la Iglesia, y por lo tanto inasumible ${ }^{62}$.

En vísperas del vencimiento del plazo de 1 año para la constitución de las asociaciones cultuales (12 de diciembre de 1906), se han creado casi 2.000 asociaciones protestantes y judías, pero prácticamente ninguna católica. Por medio de una Circular de 1 de diciembre de 1906, Briand establece que las iglesias permanecerían abiertas al público, pero el clero las utilizaría a título de meros precaristas, es decir, en calidad de ocupantes sin título jurídico. Las casas parroquiales pasarían a los ayuntamientos, las cuales serían arrendadas a los sacerdotes, y los palacios episcopales y seminarios entrarían a manos del Estado y los departamentos. Pío X rechaza esta solución nuevamente el 16 de diciembre, impartiendo instrucciones a los sacerdotes para que éstos continuaran celebrando los oficios religiosos, absteniéndose de realizar cualquier tipo de declaración administrativa, al entender que los templos, lugares consagrados a Dios, han sido puestos en una situación peor a la de una sala de baile, y de celebrar contratos de arrendamiento con relación a los lugares de culto y demás edificios eclesiásticos, colocados bajo secuestro, salvo en caso de absoluta necesidad ${ }^{63}$.

61 Patrick Cabanel, 1905, la séparation des Églises et de l'État en 30 questions, Geste, La Crèche, 2005, pp. 13 y 14. Los susceptibles de ser denominados assomptionnistes. Jean-Marie MAYEUR, La separation de l'Eglise et de l'État (1905), Firmin-Didot, París, 1966, pp. 163 y 164. Philippe PORTIER, L'épiscopat français et la loi de Séparation. Retour sur un processus de reconnaissance, en Patrick WEIL, Politiques de la Laïcité au XXe siècle, PUF, París, 2007, p. 210.

62 Maurice BARBIER, La Laïcité, L'Harmattan, París, 1995, p. 53. Christian SORREL, Les évéques à l'beure de la Séparation, en Jean-Pierre Chantin y Daniel Moulinet (dir.), La Séparation de 1905. Les hommes et les lieux, Les editions de l'atelier, París, 2005, p. 59.

63 Emmanuel BARBIER, Histoire du catholicisme liberal et du catholicisme social en France. Du Concile Vatican à l'avènement de S.S. Benoît XV (1870-1914), t. 4, Imp. Cadoret. Burdeos, 1923-1924, pp. 165-166. Jean Paul SCOT, L'État chez lui, l'Église chez elle. Comprendre la loi de 1905, Le Seuil, París, 2005, pp. 290 y ss. 
El Gobierno hace aprobar una nueva Ley, que ve la luz el 2 de enero de 1907, por la que, las iglesias quedan a disposición de los fieles y de los ministros de culto para la práctica de su religión, añadiendo que hasta su desafectación regular. Pío X rechazará la fórmula por la encíclica de 6 de enero, Une Fois Encore ${ }^{64}$, con un tono apocalíptico ${ }^{65}$.

\section{BÚSQUEDA DE UNA ENTENTE CORDIALE CON LA IGLESIA CATÓLICA}

\section{V.1. Introducción}

La reincorporación de los 3 departamentos de Alto Rin, Bajo Rin y Mosela, bajo soberanía de Francia una vez terminada la I Guerra Mundial, se hace con el acuerdo de respetar la vigencia del Concordato de 1801 en los mismos, comprometiéndose el Estado a correr con el sostenimiento de los ministros de los cultos reconocidos, respetar la confesionalidad de la escuela, y el mantenimiento de la enseñanza religiosa ${ }^{66}$.

Se trataba de trazar un itinerario de regreso a Roma, sin pasar por Canossa. Un acontecimiento puntual que permite avanzar en el proceso de descongelación de la situación, y de la reanudación de las relaciones diplomáticas es la canonización de Juana de Arco, en Roma el 16 de abril de 1920. A la ceremonia es enviada una embajada francesa extraordinaria, encabezada por Gabriel Hanotaux, ex Ministro de Asuntos Exteriores y embajador extraordinario, aunque los cardenales y obispos franceses presentes en la misma hacen saber sus recelos. La Ley de 10 de julio de 1920 declara fiesta nacional de la Patria, a la festividad de Juana de Arco. Estas celebraciones servirán de preludio al restablecimiento de relaciones diplomáticas en 1921.

El 22 de enero de 1922, fallece Benedicto XV, su sucesor, Pío XI pronto muestra su petición de una nueva Ley sobre el culto católico, pero la nueva Cámara, aunque es de color conservador, tiene una clara orientación laica, y no parece estar dispuesta a acceder a todas las pretensiones que vengan del Vaticano ${ }^{67}$.

64 Philippe PORTIER, L'épiscopat français et la loi de Séparation. Retour sur un processus de reconnaissance, en Patrick WeIL, Politiques de la Laïcité XXe siècle, PUF, París, 2007, p. 210. Émile POULAT, Les Diocesáines, La documentation Française, París, 2007, pp. 101 y ss.

65 Emmanuel BARBIER, Histoire du catholicisme liberal et du catholicisme social en France. Du Concile Vatican à l'avènement de S.S. Benoît XV (1870-1914), t. 4, Imp. Cadoret, Burdeos, 1923-1924, p. 165. Pierre PIERRARD, Un siècle de l'Église de France. 1900/2000, Desclée de Brouwer, París, 2000, p. 47.

66 André Latreille y René RÉmOND, Histoire du Catholicisme en France. III. La période Contemporaine, Editions Spes, París, 1962, 2a ed., p. 563.

67 Émile Poulat, Aux carrefours stratégiques de l'Église de France. XXe siècle, Berg International, París, 2009, pp. 58 y ss. Émile POUlat y Maurice GELBARD, Scruter la loi de 1905. La République française et la Religion, Fayard, Millau, 2010, p. 311. 


\section{V.2. El paso de las asociaciones cultuales a las asociaciones diocesanas}

La indefinición en que había quedado el estatuto jurídico de la Iglesia, a raíz del rechazo de la Ley de separación, y la negativa de Pío X a la constitución de las denominadas asociaciones cultuales, no era para nada beneficioso.

En 1923 se trabaja por llegar a un acuerdo entre ambas partes sobre un proyecto de asociaciones cultuales diocesanas, que sin necesidad de modificar la redacción de la Ley de separación de 1905, ni de retirar las declaraciones pontificias de condena que pesaban sobre la misma, permitirá por vía interpretativa llegar a un acuerdo que fuera asumible por todos. Es decir, se estaba buscando una fórmula que fuera aceptable por la Santa Sede, y que a la par fuese conforme a la Ley de $1905^{68}$.

La fórmula de las asociaciones diocesanas es el resultado de unas largas negociaciones, y comienza a cristalizar cuando el 7 de mayo de 1923, el nuncio apostólico entrega un primer boceto de texto legal al Presidente del Consejo, Raymond Poincaré, que permitirá la creación de las denominadas associations diocésaines bajo un estatuto especial, que actuarían bajo la autoridad del obispo, en comunión con la Santa Sede y en conformidad con la constitución de la Iglesia católica ${ }^{69}$.

La opinión del Consejo de Estado de 13 de diciembre de 1923, reconocerá la legalidad del nuevo estatuto de las associations diocésaines ${ }^{70}$. La encíclica Maximam Gravissimamque, de 18 de enero de 1924, de Pío XI autorizará el establecimiento de asociaciones diocesanas ${ }^{71}$, y entre 1924 y 1926, se despliega el proceso de constitución de las mismas, a razón de una por diócesis (23 de ellas en 1924, y 18 más en 1925$)^{72}$, algo que muy bien pudiera haber sido hecho 17 años antes, eso sí, siempre que se hubiera tenido un poco más de tacto y habilidad negociadora ${ }^{73}$.

68 Maurice LARKIN, L'Église et l'État en France. 1905: La crise de la Séparation, Privat, Toulouse, 2004, pp. 242 y ss. Émile POULAT, Aux carrefours stratégiques de l'Église de France. XXe siècle, Berg International, París, 2009, pp. 58. Émile Poulat y Maurice GELBARD, Scruter la loi de 1905. La République française et la Religion, Fayard, Millau, 2010, p. 312.

69 Corinne BONAFOUX, La relance de la question de la laïcité au tournant des années 1920, en Patrick WEIL, Politiques de la Laïité au XXe siècle, PUF, París, 2007, p. 287.

70 Jean Michel Ducomte, La Loi de 1905. Quand l'État se séparait des Églises, Milan, Toulouse, 2005, p. 35 .

71 Émile Poulat, Les Diocesáines, La documentation Française, París, 2007, pp. 397 y ss.

72 Philippe PORTIER, L'épiscopat français et la loi de Séparation. Retour sur un processus de reconnaissance, en Patrick WEIL, Politiques de la Laïcité au XXe siècle, PUF, París, 2007, p. 221.

73 Maurice LARKIN, L'Église et l'État en France. 1905: La crise de la Séparation, Privat, Toulouse, 2004, pp. 242-243. Émile POULAT, Aux carrefours stratégiques de l'Église de France. XXe siècle, Berg International, París, 2009, p. 59. 
Pero habrá de esperarse al Decreto Ley del mariscal Petain de 15 de febrero de 1941, que restituye a la Iglesia los bienes que le fueron incautados a raíz de la aplicación de la Ley de separación y que no habían sido adjudicados a terceros a esa fecha. Larkin entiende que aquello pudo representar apenas un 1\% del valor a precios constantes de aquello a lo que la Iglesia había rehusado en 1906, con su negativa a constituir las asociaciones cultuales. Pese a todo ello, desde un punto de vista pragmático, poco era mejor que nada ${ }^{74}$.

\section{V.3. La II Guerra Mundial y el Régimen de Vichy}

La Ley de 3 de septiembre de 1940, publicada poco antes del comienzo del nuevo curso escolar, deroga en su artículo único, el artículo 14 de la Ley de 1 de julio de 1901 y la Ley de 7 de julio de 1904, mejorando el régimen jurídico de las congregaciones religiosas en lo que concierne al sistema educativo, suprimiendo la prohibición de ejercer la enseñanza y dirigir centros educativos, que pesaba sobre los miembros de las congregaciones religiosas no autorizadas. El 6 de enero de 1941, se restablece la enseñanza facultativa de la religión en las escuelas públicas $^{75}$.

La Ley de 15 de febrero de 1941, procede a restituir a las asociaciones diocesanas católicas, bienes destinados al culto católico que pertenecieron en épocas pasadas a algún establecimiento público de culto, que aún no hubieran sido objeto de ningún decreto de atribución. Algunos de éstos tendrán una profunda carga simbólica, como ocurre con la gruta de Lourdes, que es entregada a la asociación diocesana de Tarbes. Esta norma será prorrogada por el 31 de diciembre de 1942, por una duración de 6 meses después del cese de las hostilidades ${ }^{76}$.

La Ley de 2 de noviembre de 1941 permitirá a los departamentos conceder subvenciones a favor de los centros docentes privados, sobre la base de la precariedad de sus recursos, lo cual pudiera conllevar su cierre ${ }^{77}$. Una Ley de 8

74 Maurice LARKIN, L'Église et l'État en France. 1905: La crise de la Séparation, Privat, Toulouse, 2004, pp. 244-245.

75 Maurice BARBIER, La Lä̈ité, L'Harmattan, París, 1995, p. 56. Jean ÉTÈVENAUX, L'Église et l'État. La grand bistoire de la lä̈ité, Saint-Léger Éditions, 2012, p. 195. Jean Michel DUCOMTE, La Loi de 1905. Quand l'État se séparait des Églises, Milan, Toulouse, 2005, p. 40. Jean-Marie MAYEUR, La question lä̈que. XIX'-XX' siècle, Fayard, 1997, p. 162.

76 Jean ÉTĖVENAUX, L'Église et l'État. La grand histoire de la laïité, Saint-Léger Éditions, 2012, p. 196. Jean Michel DuCOMTE, La Loi de 1905. Quand l'État se séparait des Églises, Milan, Toulouse, 2005 , p. 41.

77 Jean BAUBÉROT, Histoire de la lä̈ité en France, Presses Universitaires de France, París, 2000, p. 100. 
de abril de 1942 suprime el delito de congregación no autorizada ${ }^{78}$. Y la Ley de 25 de diciembre de 1942, modifica el artículo 19 de la Ley de 9 de diciembre de 1905 , permitiendo a las asociaciones diocesanas recibir liberalidades testamentarias y entre vivos, destinadas al cumplimiento de su objeto ${ }^{79}$.

\section{V.4. La reinstauración republicana al terminar la II Guerra Mundial}

La Constitución de 1958 volverá a definir Francia, como una República laica, sin definir esta última palabra ${ }^{80}$.

El 31 de diciembre de 1959, la Ley Debré resuelve el problema de la guerra escolar, al entender que la enseñanza privada ba adquirido sus cartas de nobleza republicana, permitiendo a los establecimientos de enseñanza privados con ideario propio, en su inmensa mayoría de titularidad católica, la posibilidad de ser financiados con fondos públicos, y sentó las bases de los centros concertados con contrato simple o de asociación, suponiendo un jaque mate a la laicización total del sistema educativo, siendo objeto de una profunda controversia social, recogiéndose infructuosamente en su contra 11 millones de firmas. La Ley es aprobada en la Asamblea Nacional por 427 votos a favor y únicamente 71 votos en contra (entre ellos básicamente parlamentarios comunistas y socialistas) ${ }^{81}$.

\section{CONCLUSIONES}

Las causas que justifican la génesis de la Ley de separación pueden ser de dos tipos: coyunturales y estructurales. Las primeras explicarían su origen en una serie de hechos puntuales e imprevistos, que se concatenan en un breve período de tiempo, como son el affaire Dreyfus y sus consecuencias, el resultado de la ofensiva anticlerical frente a la intransigencia teocrática de Pío X (por otro lado comprensible en su contexto histórico) ${ }^{82}$, la crisis por las nominaciones episco-

78 Jean ÉTÈvenaux, L'Église et l'État. La grand histoire de la laïité, Saint-Léger Éditions, 2012, pp. 196-197. Jean BAUBÉROT, Histoire de la laicité en France, Presses Universitaires de France, París, 2000, p. 99. André LATREILlE y René RÉMOND, Histoire du Catholicisme en France. III. La période Contemporaine, Editions Spes, París, 1962, 2a ed., p. 613.

79 Maurice BarbIER, La Lä̈cité, L'Harmattan, París, 1995, p. 56. Jean ÉTÈVENAUX, L'Église et l'État. La grand histoire de la laïité, Saint-Léger Éditions, 2012, p. 196.

80 Maurice BARBIER, La Laïcité, L'Harmattan, París, 1995, pp. 63 y 64.

81 Jean-Pierre DelanNoy, Le centenaire de la Loi de Separation du 9 decembre de 1905: Commemoration d'un Evenement juridique ou reaffirmation du príncipe du lä̈cité? en Anuario de Derecho Eclesiástico del Estado, 22 (2007), p. 436. Jean-Michel DuCOMTE, La laicicité, Milan, Toulouse, 2009, p. 62.

82 Jean SÉVILLIA, Quand les catholiques étaient hors la loi, Perrin, París, 2006, p. 191. 
pales, y la ruptura del Concordato y de relaciones diplomáticas entre París y el Vaticano. Quizás la historia hubiera sido muy distinta si Combes no hubiera sustituido a Waldeck-Rousseau, el 6 de junio de 1902, o si a la muerte de León XIII, el 20 de julio de 1903, su sucesor hubiera sido el francófilo Rampolla en lugar del poco diplomático Patriarca de Venecia, Giuseppe Sarto, el futuro Pío X. Pero también cabe una explicación estructural, que se basa en una perspectiva a largo plazo, que situaría a la Ley de separación como el resultado de una larga evolución histórica que supone el final del modelo concordatario de cultos reconocidos diseñado por Napoleón, y con ello los últimos vestigios del Antiguo Régimen que unían a una Iglesia aún nacional, con un Estado incompletamente secularizado. Sería el colofón de un proceso que se inicia en la Edad Media con las luchas entre Felipe IV, el Hermoso, y Bonifacio VIII, y que encuentra su continuación en el Renacimiento con la Reforma y la lucha por el reconocimiento de la libertad religiosa, o al menos de la tolerancia, y tiene su penúltima etapa en la Revolución, cuya obra secularizadora habría sido cerrada en falso por Bonaparte ${ }^{83}$.

A pesar del carácter moderado de alguno de sus protagonistas, como Briand, la separación va a ser abrupta, al tener lugar en un clima viciado y conflictivo. La Ley es adoptada por una amplia mayoría parlamentaria, pero con una oposición importante (341 diputados a favor frente a 233 en contra y 181 senadores contra 102), y muchas de sus disposiciones o bien son inadaptadas, o resultan muy difíciles de aplicar, por lo que resulta inadecuado, o cuando menos excesivo, hablar de la existencia de un pacto laico. El prestigioso constitucionalista Duguit, enemigo por cierto de los sistemas de representación mayoritaria y defensor de los sistemas proporcionales, criticará el modo de formación de las mayorías parlamentarias entre 1881 y 1919, por no representar más que a una minoría del país, al entender que no es sino un falso señuelo creer que son fiel imagen de la mayoría de Francia, y de forma estimada calculará, que los 341 diputados que aprueban la Ley, representaban a 2.647.315 electores, sobre un total de 10.967 .000 inscritos, es decir, un cuarto del total ${ }^{84}$. No fue una Ley negociada, sino impuesta a la Iglesia. Es percibida por la Iglesia de forma desgarrada como una sanción, y un acto de hostilidad. Paradójicamente, la separación se hace de modo incompleto, pues se limita a suprimir la financiación pública a las confesiones religiosas, pero reserva al Estado determinadas prerrogativas que son abusivas, que exceden sus compe-

83 Jean Paul SCOT, L'État chez lui, l'Église chez elle. Comprendre la loi de 1905, Le Seuil, París, 2005, pp. 117-118.

84 Léon Duguit, Traité de Droit Constitutionnel, Tomo II, ed. Boccard, París, 1927, pp. 728 a 732. Émile POULAT, Notre laïcité publique. «La France est une République laïque», Berg, París, 2003, p. 112. 
tencias legítimas, como la imposición de un patrón organizativo homogéneo (el de las asociaciones cultuales), a una serie de confesiones religiosas de muy diversa naturaleza y características organizativas, desconociendo la especificidad de la Iglesia católica ${ }^{85}$.

La Ley de 9 de diciembre de 1905 va a suponer una derogación unilateral del Concordato, por parte de la República francesa, sin negociación previa con la Santa Sede, y por lo tanto constituye desde un punto de vista técnico una vulneración del Derecho Internacional, tal y como recuerda Rimbaud ${ }^{86}$, el cual señala que Duguit ${ }^{87}$ lo considerará como un grave error desde un punto de vista sociológico, y una violación manifiesta del Derecho Internacional, pues todo Tratado Internacional debe ser formalmente objeto de una denuncia previa, antes de poder procederse a su derogación mediante un acto del derecho interno. A ello cabría objetar como señala Esmein ${ }^{88}$, que en realidad ninguna de las dos partes, ni la Iglesia, ni el Estado, se preocuparon lo más mínimo sobre la ausencia de una denuncia formal del Concordato, pues en realidad la voluntad de ambas partes estuvo suficientemente clara en todo momento. Todo ello sin olvidar, como indica Rimbaud, que el propio Gobierno republicano tenía motivos suficientes para entender que el Concordato había sido incumplido por la Santa Sede en el asunto de los obispos de Laval, monseñor Geay, y de Dijon, monseñor Le Nordez, desde el momento que el artículo XX de los artículos orgánicos, impedían la correspondencia directa entre el nuncio y los obispos franceses, que habían sido llamados a capítulo por Roma, por su conducta al frente de sus respectivas diócesis ${ }^{89}$.

La liquidación del Concordato, que a principios del siglo xx suponía un fenómeno extraño en el ordenamiento jurídico francés, como diría Reveillaud, era un anciano decrépito que agonizaba, fue algo que a largo plazo probablemente resultó más beneficioso que perjudicial, para la Iglesia, aunque en el momento en que ello tiene lugar no fuera necesariamente visto así, pues el Estado perdió un instrumento de control e injerencia en los asuntos internos de la Iglesia, a través de la poderosa herramienta de la designación episcopal. A pesar de ello desde la Iglesia se tenía la percepción de ser mejor mantener el Concordato, a pesar de

\footnotetext{
85 Maurice BARBIER, La Laïcité, L'Harmattan, París, 1995, pp. 50-51.

86 Thierry RIMBAUD, Le principe de séparation des cultes et de l'État en Droit public comparé, LGDJ, París, 2004, pp. 76-78.

87 Léon DUGUIT, Traité de droit constitutionnel, t. 5, $2^{\mathrm{a}}$ ed., pp. 527-534.

88 Adhémar EsMEIN, Eléments de droit constitutionnel français et comparé, t. 2, Sirey, París, 1921, p. 617.

89 Maurice Hauriou, Principes de Droit Public, Sirey, 1910, pp. 404- 405.
} 
sus imperfecciones, eso sí por razones diversas, y no necesariamente coincidentes en el seno de la propia Iglesia. Para el clero francés, porque creía que lo que estaba en juego era su supervivencia económica, para el Vaticano era una cuestión de prestigio internacional, no en vano el respeto internacional era una cuestión prioritaria en la grave crisis que se extiende desde 1870, en que el papado ha perdido los últimos vestigios de su soberanía territorial, hasta 1929, fecha de la firma de los Pactos de Letrán, prevaleciendo dicha preocupación por el prestigio sobre lo que hubiera dictado el buen sentido, y la necesidad de puesta al día de viejos compromisos internacionales que comenzaban a carecer de sentido. De hecho, en los sectores políticos más anticlericales de la III República, se era plenamente consciente que con la denuncia del Concordato, la Iglesia saldría reforzada, a pesar de perder la financiación pública del culto, pues tendría plena libertad para la elección de su personal, especialmente el llamado a ocupar las sedes episcopales, claves en su estructura jerárquica, y podría organizar libremente sus actividades, lejos de la agobiante presión de la vigilante tutela del Estado ${ }^{90}$.

Con la consolidación del principio de laicidad del Estado, la Iglesia y el Estado se separan, no por acuerdo mutuo, sino de forma abrupta, primero de hecho, y luego de derecho. Ello supone también un antes y un después en la historia de las relaciones entre la Iglesia y el Estado en Francia, supone el final de un movimiento neogalicano en que el Estado soberano aspira a ejercer el control sobre una Iglesia sumisa al mismo, y cuyo último heredero será el mismísimo Combes, partidario de mantener el control sobre las nominaciones episcopales, al utilizar el Concordato napoleónico como un instrumento con el que ejercer un control sobre la Iglesia ${ }^{91}$.

Un significativo sector de los católicos franceses vivirán como un verdadero drama la discusión, aprobación y puesta en práctica de la Ley de separación, al hacer saltar por los aires el manto protector que representaba el Concordato. Con el fin de la tutela estatal, desaparecen también algunos de sus efectos colaterales, como la injerencia estatal en la designación de las diócesis católicas y la dependencia económica frente al Estado, que no necesariamente redundaban en beneficio de la Iglesia, la cual recupera su plena autonomía organizativa y su in-

90 Yves-Marie HILAIRE y Rémi FABRE, Vers de nouveaux rapports entre les Eglises et l'Etat, en Gérard ChOlvy e Yves-Marie Hilaire, Histoire religieuse de la France Contemporaine. 1880/1930, Privat, Toulouse, 1986, p. 107. Maurice LARKIN, L'Église et l'État en France. 1905: La crise de la Séparation, Privat, Toulouse, 2004, pp. 29 y 30.

91 Jean Paul Scot, L'État chez lui, l'Église chez elle. Comprendre la loi de 1905, Le Seuil, París, 2005, pp. 341 y 344. 
dependencia material frente al poder público. A largo plazo ambas consecuencias redundarán en la configuración de una Iglesia más libre e independiente, aunque de ello no se dieran cuenta muchos de los católicos que hace un siglo vivieron en primera persona el desarrollo de los acontecimientos, como un auténtico drama.

La separación se lleva a cabo de modo unilateral e incompleto.

1) Es el Estado quien decide poner fin a su compromiso previo de financiar a los cultos reconocidos. Es algo perfectamente posible desde el punto de vista de su plena soberanía legislativa. Pero lo hace con cierta torpeza, y sin concertación con las confesiones religiosas afectadas, sin molestarse en denunciar formalmente el Concordato con la Santa Sede, con la cual se acaban de romper relaciones diplomáticas en 1904. A ello hay que unir que a pesar de la moderación de algunos de sus protagonistas, como Briand, se realiza en malas condiciones y en un clima de conflicto. Se adopta por una clara mayoría parlamentaria, pero también con una importante oposición, que impide hablar de la existencia de un pacto laico, o al menos, hacerlo sin falsear la realidad ${ }^{92}$. Aunque algunos autores como Baubérot han defendido con ardor la idea de un pacto laico $0^{93}$, que ha seducido especialmente a la Federación protestante de Francia y a la Ligue française de l'enseignement, llegándose a elaborar en 1989 el documento Vers un nouveau pacte lä̈que?, lo cierto es que algunos autores no dejan de mostrar una cierta distancia sobre dicha apreciación de los hechos históricos, hablando con sutil ironía del pacto no encontrable, para ello Poulat se basa en que dicha idea pactista descansa sobre una ficción sociológica, de un pacto anterior, del cual nadie ha oído hablar. La Ley de separación no surge de un acuerdo entre las partes implicadas, sino más bien un acto de fuerza, viniendo a poner fin a la obra laica acometida por la Revolución, y que había sido clausurada por el Concordato. Por lo tanto si estamos ante un pacto, habría que definir dónde y cuándo tuvo lugar, entre qué actores y sobre qué base. En 1905 los espíritus estaban enfrentados, las posiciones contrapuestas, y de tal manera rígidas que resulta quimérico, e incluso superfluo, tratar de buscar un punto común de consenso ${ }^{94}$.

2) Se pone en práctica de un modo incompleto, al contemplarse excepciones de carácter geográfico (Alsacia-Mosela y territorios de ultramar), y de comprensión de la misma, y aplicándose de un modo sui generis. Así, el peso de la historia

\footnotetext{
92 Maurice BARBIER, La Laïcité, L'Harmattan, París, 1995, p. 50.

93 Jean BAUBÉROT, Vers un nouveau pacte läque?, Seuil, París, 1990.

94 Émile Poulat, Notre laïcité publique. «La France est une République laïque», Berg, París, 2003, pp. 106 a 108.
} 
ha creado una situación particular, sorprendente en un país laico, centralizado y cartesiano $^{95}$.

La Ley de separación de 1905 será vista por un amplio sector de los católicos franceses como una norma hostil, una ley de combate y una monstruosa injusticia, que será condenada por el Papa. La Ley de 1905 no privará a las confesiones religiosas del uso de los lugares de culto, instándose a las mismas a constituir las oportunas asociaciones cultuales, un traje que presenta especiales problemas de adaptación en el caso de la Iglesia católica, debido a su peculiar estructura jerarquizada, que sitúa a los obispos al frente de las respectivas diócesis, por ello se hará necesario llevarlo al sastre, para que ajuste el patrón al cliente, surgiendo de este modo las asociaciones diocesanas. Así, la Iglesia católica acabará también pasando bajo el aro de la separación ${ }^{96}$.

La Ley de separación de 1905 contribuye a consolidar en Francia un modelo de derecho común, demostrando una especial plasticidad para adaptarse a la evolución de la realidad francesa que la ha hecho pervivir por espacio de más de un siglo. El Concordato napoleónico en realidad era un arma de doble filo para la Iglesia católica, pues le hacía extraordinariamente dependiente del poder establecido, al estar condicionada respecto al mismo económicamente, y al producirse una intensa intervención del poder civil en el nombramiento de la jerarquía eclesiástica.

Coincidimos con Areces Piñol en que el balance que se puede hacer un siglo después de la instauración del principio de laicidad en Francia a través de la Ley de separación de 1905, es en principio positivo, pues superados los conflictos iniciales, la laicidad francesa ha terminado por asentarse sobre el diálogo entre el poder civil y las confesiones religiosas, incluida la Iglesia católica, a partir de una pragmática adaptación a los nuevos retos planteados ${ }^{97}$.

95 Guy Bedouelle y Jean-Paul CoSTA, Les lä̈ités à la française, PUF, París, 1998, p. 149. Alain BOYER, La loi de 1905: de la guerre au dialogue. Réflexions autour de la loi de 1905, en Nicolas MARTY y Bruno Gaudelet (dir.), Centenaire de la Loi de Séparation des églises et de l'État du 9 décembre 1905, Presses Universitaires de Perpignan, Perpignan, 2007, pp. 38 y ss.

96 Alain BOYER, Le droit des religions en France, Presses Universitaires de France, París, 1973, pp. 45 y 46.

97 María Teresa Areces PIÑOL, Francia: Cien años de laicidad, en Laicidad y Libertades. Escritos Furídicos, $5(2005 / 1)$, p. 94. 